LISANUL ARAB 10 (1) (2021)
(Terakreditasi Sinta 4)

\title{
PEMBELAJARAN BAHASA ARAB DI ERA PANDEMI: IMPLEMENTASI $E$ - LEARNING DI SEKOLAH DASAR ISLAMIC GLOBAL SCHOOL KOTA MALANG
}

\author{
Achmad Sirojul Munir ${ }^{\bowtie}$, Muassomah Muassomah ${ }^{\bowtie}$
}

Universitas Islam Negeri Maulana Malik Ibrahim Malang

\begin{tabular}{l} 
Info Artikel \\
\hline Sejarah Artikel: \\
Diterima Maret 2021 \\
Disetujui April 2020 \\
Dipublikasikan April \\
2021
\end{tabular}

Keywords:

The Covid-19 Pandemic, ELearning, Arabic Language Learning

\begin{abstract}
Abstrak
Penelitian ini mendiskripsikan tentang implementasi e-learning dalam pembelajaran Bahasa Arab di Sekolah Dasar Islamic Global School, Kota Malang selama pandemi Covid-19. Metode penelitian ini menggunakan jenis penelitian kualitatif, dengan data berupa berupa deskriptif. Pengumpulan data yang digunakan yaitu dengan cara observasi, wawancara, dan dokumentasi. Adapun hasil penelitian ini, sebagai berikut: 1). Pelaksanakan pembelajaran e-learning di SD Islamic Global School menggunakan 5 media utama, yaitu: google classrom, whatsAap, you tube, zoom, dan quizizz. 2). Implementasi e-learning dalam pembelajaran Bahasa Arab di SD islamic Global School terdiri dari 3 langkah utama, yaitu; pendahuluan, kegiatan inti, dan evaluasi. 3). Dalam pelaksanakan pembelajaran Bahasa Arab berbasis e-learning di SD Islamic Global School terdapat kelebihan dan kekurangan. Adapun kelebihannya ada 3, yaitu: memberikan kesempatan bagi siswa dan guru untuk lebih kreatif dan inovatif, memberikan waktu yang fleksibel, dan memberikan kemudahan akses terhadap sumber belajar. Sedangkan, kekurangannya ada 3 juga, yaitu: tidak semua siswa memiliki HP android ataupun laptop guna menunjang pelaksanakan pembelajaran Bahasa Arab berbasis elearning. Akses internet tidak merata, minimnya pengawasan serta berkurangnya interaksi antar guru dan siswa dalam proses kegiatan belajar mengajar.
\end{abstract}

\begin{tabular}{ll}
\hline Alamat korespondensi: & P- ISSN 2252-6269 \\
UIN Maulana Malik Ibrahim Malang & E- ISSN 2721-4222 \\
E-mail: achmadsirojulmunir@gmail.com, muassomah@bsa.uin-malang.ac.id &
\end{tabular}




\section{PENDAHULUAN}

Pandemi corona virus disease 2019 (Covid2019) bukan hanya merupakan krisis kesehatan, tetapi juga masalah sosial termasuk pendidikan. Pergeseran pendidikan dari konvensional ke instrumental berbasis teknologi telah terjadi seiring dengan dikeluarkannya kebijakan pemerintah tentang social dan physical distancing. Pembelajaran daring dilakukan sebagai pilihan utama dalam memutus penyebaran covid-19 di dalam dunia pendidikan (Yudiawan, 2020: 12). Berdasarkan Surat Edaran Nomor 4 Tahun 2020, Mendikbud menghimbau agar semua lembaga pendidikan tidak melakukan proses belajar mengajar secara langsung atau tatap muka, melainkan harus dilakukan secara daring (Pusdiklat Kemendikbud, 2020: 22). Sebagai solusi dari fenomena tersebut, maka satuan pendidikan mulai dari sekolah dasar hingga perguruan tinggi menyelenggarakan pendidikan secara online atau dalam jaringan (daring). Hal inilah yang menjadi dasar utama peneliti untuk melakukan penelitian tersebut. Adapun tujuan dilakukannya penelitian ini adalah untuk mengetahui bagaimana implementasi pembelajaran e-learning dalam pembelajaran Bahasa Arab selama di Era Pandemi covid-19 di Sekolah Dasar Islamic Global School, Kota Malang.

Pembelajaran daring atau e-learning merupakan bentuk pembelajaran jarak jauh yang menggunakan teknologi dan informasi, misalnya internet (Mustofa dkk, 2019: 153). Jadi, pembelajaran daring dilakukan tanpa bertemu fisik dan berjarak, (Henderson, 2003: 32) dengan menggunakan jaringan internet yang baik (Clark, R.C. \& mayer, 2003: 52). Sehingga, pembelajaran ini dirasa cukup relevan dengan pencegahan penyebaran covid-19 melalui social distancing dan fisikal distancing (GTPPCovid-19, 2020: 15).

Sejauh ini, studi tentang pembelajaran daring di era covid-19 memiliki empat kecenderungan, yaitu: pertama, kajian tentang dampak covid-19 terhadap pembelajaran daring (Juanda, 2014: 79); (Latip, 2020: 108); dan (Windhiyana, 2020: 1). Kedua, kajian tentang motivasi belajar siswa dalam pembelajaran daring (Cahyani, et al., 2020: 123). Ketiga, kajian tentang proses pembelajaran daring selama covid-19 (Husna, 2020: 145). Keempat, bentuk evaluasi pembelajaran daring selama covid-19 (Irawati \& Jonatan, 2020: 135). Dari empat kecenderungan ini, implementasi dalam pembelajaran daring masih belum dilakukan secara komprehensif. Karena dengan mengetahui implementasi pelaksanaan daring tersebut bisa diketahui bagaimana desain pembalajaran daring selama pandemi covid-19.

Berdasarkan uraian di atas, maka penelitian ini dapat difokuskan dengan dua pembahasan, yaitu: 1). Media apa sajakah yang digunakan dalam pembelajaran daring di Sekolah Dasar Islamic Global School selama Pandemi Covid-19?. 2). Bagaimana implementasi pembelajaran daring di Sekolah Dasar Islamic Global School selama pandemi Covid-19?. 3). Bagaimana kelebihan dan kekurangan pelaksanaan pembelajaran e-learning selama pandemi covid-19?.

\section{LANDASAN TEORI \\ Konsep Dasar e-Learning}

Secara bahasa, e-learning berasal dari 2 kata Bahasa Inggris, yaitu elektronic dan learning (Mutia \& Leonard, 2013: 280). Adapun secara istilah e-learning merupakan pembelajaran yang dilakukan dengan menggunakan media elektronik. Lebih lanjut, Jethro., et al (2012: 206) menambahkan bahwa e-learning mengacu pada penggunaan internet dan teknologi untuk memberikan beragam solusi untuk meningkatkan pengetahuan dan keterampilan peserta didik. Pengertian yang sama juga disampaikan oleh Horton dalam Kattoua., et al (2016: 754) yang menyatakan bahwa e-learning merupakan seperangkat pembelajaran yang disampaikan melalui media elektronik, seperti internet, intranet, dan extranet. Dari pengertian di atas, bisa disimpulkan bahwa e-learning bertujuan untuk meningkatkan pengetahuan dan keterampilan peserta didik melalui media teknologi dan internet, seperti penggunaan video, website, dan audio.

Implementasi e-learning dapat mudah dikenali dengan adanya pemanfaatan teknologi 
dan media elektronik dalam proses pembelajaran. E-learning ini diharapkan mampu memberikan kesempatan bagi peserta didik untuk melakukan eksplorasi terhadap topik pembelajaran yang bersumber dari internet. Sehingga, e-learning memungkinkan peserta didik untuk memperoleh pengalaman (experience) belajar sesuai dengan kemampuan, dan minat bakatnya, serta menumbuhkan kreatifitas dan kemampuan berfikir kritis (Damayanti, 2020: 66).

Menurut Gottschalk dalam Mutia \& Leonard $(2013,282)$ menyebutkan bahwa elearning memiliki 5 komponen penting dalam pelaksanakannya. Adapun komponenkomponen itu sebagai berikut: Pertama, peserta didik. Peserta didik merupakan komponen utama dalam e-learning. Jika peserta didik tidak ada, maka e-learningpun juga tidak bisa digunakan. Karena e-learning dikatakan efektif jika mampu memfasilitasi kebutuhan peserta didik. Kedua, Instruktur. Dalam proses belajar mengajar, instruktur memiliki peranan penting dalam e-learning. Seorang instruktur harus mengetahui kebutuhan dan karakteristik peserta didik, supaya bisa merancang e-learning yang baik. Selain itu, instruktur juga berperan sebagai pendamping yang selalu membimbing peserta didik dalam mengoperasikan e-learning ketika dalam kegiatan belajar mengajar.

Ketiga, fasilitator. Dalam e-learning, fasilitator dapat dikatakan sebagai komponen pendukung. Fasilitator ini merupakan perpanjangan tangan instruktur yang bertugas dalam menyiapkan peralatan, mengawasi ujian, serta mengumpulkan tugas. Keempat, staf pendukung. Staf pendukung memiliki tugas yang hampir sama dengan fasilitator, yang mana seorang staf pendukung bertugas untuk mengatur penjadwalan, duplikasi dan distribusi materi, serta pemrosesan nilai. Kelima, administrator. Administrator dalam hal ini mengarah pada fungsi manajerial yang bertugas untuk mengambil keputusan, membuat kesepakatan, serta melakukan evaluasi dan memastikan bahwa kegiatan belajar mengajar dengan menggunakan e-learning ini tetap sesuai dengan visi dan misi sekolah.

\section{Kategori e-learning}

German Faderal Academy of Public Administration dalam Belaya (2018: 95), mengklasifikasikan e-learning menjadi 4 kategori, yaitu: individual learning, tutorially suported learning, collaborative learning, dan blended learning. Adapun penjabaran dari keempat kategori e-learning, sebagai berikut:

Pertama, Individual learning. Individual learning merupakan jenis e-learning yang memberikan kebebasan bagi siswa untuk mengatur bagaimana cara belajar yang mereka sukai. Dalam bentuk ini, hanya materi dan sumber belajar yang tersedia di media yang digunakan secara online dan tidak terdapat proses monitor dari guru. Kedua, Tutorially supported learning. Jenis e-learning ini berbeda dengan individual learning. Perbedaanya terletak pada pengawasan dari guru. Jika individual learning, seorang siswa tidak mendapatkan pengawasan dari guru, sedangkan tutorially supported learning memberikan pengawasan terhadap siswa ketika proses pembelajaran elearning berlangsung.

Ketiga, Collaborative learning merupakan jenis e-learning yang mana proses pembelajaran yang terjadi dan melibatkan komunitas virtual, seperti kelas. Keempat, Blended Learning. Jenis e-learning ini merupakan gabungan dari beberapa jenis pembelajaran. Blended learning memadukan antara individual learning, pembelajaran tatap muka, serta pekerjaan kelompok.

Selain itu, Horton dalam (Mutia \& Leonard, 2013: 284) juga membagi e-learning ke dalam 5 klasifikasi utama, yaitu learner-led $e$ learning, instructor-led e-learning, facilitated $e$ learning, embeded e-learning, telementoring dan $e$ coaching. Adapun penjabarannya sebagai berikut:

Pertama, Learner-Led E-learning. Jenis ini memiliki kesamaan dengan individual learning dimana seorang siswa dapat belajar secara mandiri. Kedua, Instructor-Led E-learning merupakan jenis e-learning yang mana seorang guru menyajikan materi secara online. Hal ini seperti pertemuan tatap muka pada umumnya, namun dilakukan secara online. Ketiga, Facilitated E-Learning. Jenis ini merupakan gabungan 
anatara learned-led e-learning dan instructor-led elearning. Keempat, Embedded e-learning merupakan just in time training dimana seorang guru dapat memberikan bantuan dengan segera ketika siswa membutuhkannya. Kelima, Telementori dan ecoaching merupakan bimbingan belajar dan pelatihan jarak jauh dan dilaksanakan layaknya telekonferensi.

\section{METODE PENELITIAN}

Metode penelitian merupakan bagian yang terpenting dalam suatu penelitian. Hasil suatu penelitian dikatakan valid, jika melalui tahapan proses metode penelitian yang baik dan benar. Dalam metode penelitian ini, ada 4 tahapan yang akan peneliti uraikan, yaitu jenis penilitian, teknik pengumpulan data, teknik validasi data dan teknik analisis data.

\section{Jenis Penelitian}

Penelitian ini menggunakan penelitian kualitatif. Menurut Bogdan dan Biklen dalam Sugiyono (2019: 23), bahwa penelitian kualitatif adalah penelitian yang memiliki karakteristik bersifat deskriptif, serta datanya yang terkumpul berbentuk kata-kata atau gambar, sehingga tidak menekankan pada angka. Penelitian ini dilaksanakan di Sekolah Dasar Islamic Global School. Sekolah ini dipilih disebabkan karena lembaga pendidikan tersebut merupakan salah satu sekolah dasar di Kota Malang yang memberikan penguatan Bahasa Arab terhadap siswanya. Mata pelajaran Bahasa Arab merupakan mata pelajaran wajib yang harus diikuti oleh siswa kelas III, IV, V, dan VI. Selama pandemi covid-19 berlangsung, sekolah ini mengambil langkah belajar dari rumah melalui pembelajaran daring. Pembelajaran daring ini tentunya kurang bermakna tanpa adanya sinergitas strategi dan metode pembelajaran yang tepat. Oleh karena itu, mengetahui implementasi pembelajaran Bahasa Arab selama pandemi covid-19 di Sekolah ini dirasa sangatlah penting.

\section{Teknik Pengumpulan Data}

Teknik pengumpulan data pada penelitian ini berupa metode wawancara, observasi, dan dokumentasi. Wawancara ini dilakukan kepada
Guru Bahasa Arab SD Islamic Global School yaitu Hamidah, S.Pd. Wawancara ini bertujuan untuk menggali data seputar media apa saja yang digunakan dalam pembelajaran e-learning, serta bagaimana implementasi pembelajaran tersebut di SD Islamic Global School. Selain itu, wawancara ini juga untuk mengetahui kekurangan serta kelebihan selama proses kegiatan berlangsung. Observasi digunakan untuk meninjau serta mengamati secara langsung proses implementasi pelaksanaan pembelajaran Bahasa Arab berbasis e-learning di Sekolah Dasar Islamic Global School. Selanjutnya metode terakhir yang digunakan adalah dokumentasi, yang mana pada tahap ini menggunakan dokumentasi berupa buku ajar siswa, silabus mata pelajaran Bahasa Arab yang didapatkan langsung dari guru Bahasa Arab SD Islamic Global School.

\section{Teknik Validasi Data}

Setelah data terkumpul, tahap selanjutnya adalah validitasi data. Dalam penelitian kualitatif, temuan atau data dapat dinyatakan valid apabila tidak ada perbedaan antara yang dilaporkan dengan apa yang sebenarnya terjadi pada objek yang diteliti (Sugiyono, 2019: 363). Triangulasi dalam pengujian kredibilitas data dari berbagai sumber dengan berbgai cara, dan berbagai waktu. Dalam penelitian ini, teknik triangulasi data dilaksanakan dengan cara menguji atau membandingkan data dari guru dengan siswa selaku anak didiknya, begitu pula sebaliknya. Selain itu, juga mencocokan data hasil wawancara dengan data yang berada dalam buku panduan pembelajaran Bahasa Arab tersebut.

\section{Teknik Analisis Data}

Setelah data terkumpul, tahap selanjutnya data dianalisis. Menurut Miles dan Huberman dalam Sugiyono (2019: 321), bahwa aktivitas dalam analisis data dalam penelitian kualitatif dilakukan secara interaktif melalui tiga tahapan, yaitu data reduction, data display, dan conclusion drawing atau verification. Mereduksi data berarti merangkum, serta memilah dan memilih data yang penting, beserta polanya. 
Pada penelitian ini, langkah pertama dengan cara mencatat data hasil wawancara, observasi dan dokumentasi dalam bentuk ringkasan, lalu dipilah data tersebut sesuai dengan yang dibutuhkan. Sedangkan data display merupakan penyajian data yang membantu dalam memahami tentang apa yang terjadi dan memberi hubungan agar memungkinkan adanya kesimpulan. Setelah mereduksi data, dilakukan klasifikasi data dan mengolah data sesuai dengan apa yang diteliti yaitu implementasi metode $e$ learning dalam pembelajaran Bahasa. Adapun tahap terakhir adalah conclusion drawing atau verivication. Pada tahap ini dilakukan dengan cara menarik kesimpulan dari data-data yang telah direduksi dan diklasifikasi sebelumnya. Kemudian memaparkan hasil penelitian tersebut secara lengkap dan jelas tentang implemantasi media e-learning dalam pembelajaran Bahasa Arab di Sekolah Dasar Islamic Global School, Malang.

\section{HASIL DAN PEMBAHASAN}

Penelitian ini berfokus pada implementasi e-learning untuk mata pelajaran Bahasa Arab di Sekolah Dasar Islamic Global School, Sukun Kota Malang selama pandemi covid-19. Hasil analisis merujuk pada 2 hal penting terkait tentang implementasi e-learning, yaitu: 1). Media yang digunakan untuk melaksanakan e-learning. 2). Desain pembelajaran e-learning. 3). Keunggulan dan kelemahan pelaksanaan elearning selama pandemi covid-19 ini.

\section{Media E-learning yang digunakan di SD Islamic Global School}

Terdapat berbagai learning management system (LMS) atau system manajemen pembelajaran yang tersedia saat ini. Bahkan, pendidik dapat memanfaatkan sosial media untuk melaksanakan e-learning. Data tentang media e-learning yang digunakan di SD islamic Global Shcool ini diperoleh dari wawancara dengan Hamidah, S.Pd selaku guru bahasa Arab. Adapun hasil wawancaranya sebagai berikut:

A: Media apa saja yang digunakan di SD Islamic Global School selama pandemi covid-19 ini?
B: di dalam pelaksanakan pembelajaran Bahasa Arab selama pandemi covid-19 ini mengunakan 5 media utama, yaitu google classrom, whatsapp, zoom, you tube, dan quisis.

Google Classrom merupakan merupakan media yang paling diminati oleh pendidik atau guru dalam melaksanakan e-learning (Damayanti, 2020: 66). Media ini memberikan fasilitas untuk melakukan komunikasi interaktif dalam bentuk teks. Menurut Hamidah (wawancara pada tanggal 28 Desember 2020), bahwa media ini paling sering digunakan dalam pembelajaran daring di SD Islamic Global School untuk upload materi pelajaran Bahasa Arab sebelum pembelajaran dimulai.

Selain aplikasi google Classrom, guru juga memanfaatkan whatsApp untuk video call atau pesan video dan voice note (pesan suara). Wa ini digunakan karena penggunaannya sangat mudah dan hampir semua peserta didik memiliki aplikasi ini.

Aplikasi zoom ini memungkinkan guru dan siswa untuk bertatap muka secara online. Sehingga guru dapat memberikan instruksi dan menjelaskan materi ajar secara langsung. Menurut Hamidah, aplikasi ini digunakan ketika di awal untuk menjelaskan silabus mata pelajaran satu semester ke depan selama pandemi covid-19. Selain itu, aplikasi ini digunakan untuk menjelaskan materi maharah kalam. Karena didalam maharah kalam guru dituntut untuk mempraktikkan bagaimana pelafalan mufrodat Bahasa Arab yang baik dan benar.

You tube juga menjadi salah satu media yang dipilih oleh seorang guru dalam melaksanakan pembelajaran e-learning. Siswa dapat mengakses video yang telah diunggah oleh guru sesuai topik pembelajaran yang telah dipelajari.

Quizizz merupakan platform pembelajaran yang menggunakan sistem metode belajar mengajar melalui kuis, dimana siswa menjawab pertanyaan yang telah dibuat oleh guru, dan bersaing dengan siswa lain pada kuis yang sama. Quizizz untuk memberikan 
pekerjaan rumah kepada siswa. Menurut hamidah, quizizz ini sering digunakan untuk maharah kalam.

\section{Implementasi pembelajaran e-learning di SD Islamic Global School}

Implementasi dalam pembelajaran di SD Islamic Global School menggunakan collaborative learning. Menurut Belaya (2018: 96) dan Nurlaila, N., \& Muassomah, $(2020,150)$, collaborative learning merupakan proses pembelajaran yang terjadi dan melibatkan komunitas virtual, seperti kelas. Jadi, sebelum mengunggah materi ajar, seorang guru membuat kelas secara virtual baik menggunakan google classrom maupun whatsApp. Kemudian guru mengunggah materi dengan menggunakan aplikasi tersebut, dan memberikan penjelasan mengenai materi dan topik pembelajaran secara online beserta evaluasinya.

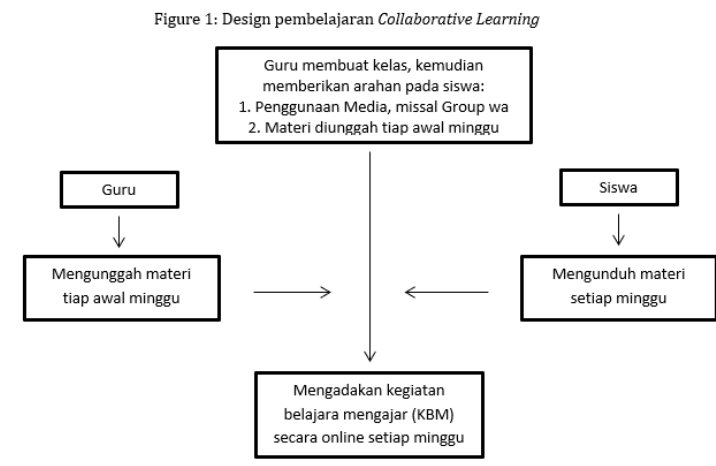

Implementasi collaborative learning dalam pembelajaran Bahasa Arab di SD Islamic Global School terdiri dari 3 tahapan, yaitu pendahuluan, kegiatan inti, dan evaluasi. Adapun penjelasan dari 3 tahapan tersebut sebagai berikut:

\section{Pendahuluan}

Pendahuluan merupakan tahap awal yang harus dilakukan oleh seorang guru dalam proses kegiatan belajar mengajar (KBM) menggunakan collaborative learning. Pada tahap ini, seorang guru mempersiapkan beberapa hal sebagai berikut secara online:

a) Guru menyiapkan silabus pembelajaran Bahasa Arab selama satu semester.

b) Guru menjabarkan tujuan pencapaian pembelajaran tersebut. c) Guru menjelaskan kepada siswa tentang tema pelajaran Bahasa yang akan dipelajari secara online baik melalui zoom.

d) Guru menjelaskan tentang penggunaan sistem collaborative learning sebagai strategi pembelajaran Bahasa Arab.

e) Guru dan siswa membuat kesepakatan tentang batas pengumpulan tugas yang harus dikerjakan secara online.

f) Guru menambahkan bahwa kelanjutan pembelajaran Bahasa Arab akan dilakukan melalui instrumen-instrumen pembelajaran yang digunakan, seperti: grup whatsapp, google classrom, you tube, zoom, dan quiziiz.

g) Sehari sebelum dimulai kegiatan belajar mengajar (KBM), guru mengunggah materi pembelajaran Bahasa Arab baik berupa maharah kalam, qiro'ah, istima', maupun kitabah di group whatsAap atau google classrom.

Figure 2: Materi yang diunggah di group wa atau google classrom.

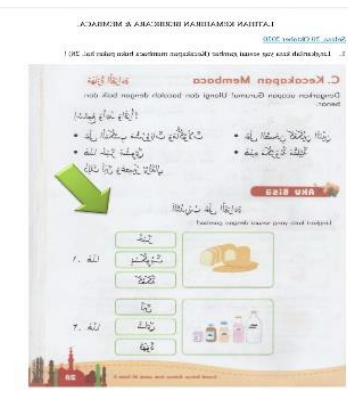

2. Kegiatan inti:

Kegiatan inti merupakan proses pelaksanakan kegiatan belajar mengajar (KBM) Bahasa Arab di SD Islamic Global School dengan menggunakan collaborative learning selama pandemi covid-19. Pada tahap ini terdapat 5 proses kegiatan inti, yaitu: mengamati, menanya, eksperiment, mengasosiasi, dan mengkomunikasikan. Penjabaran dari 5 proses kegiatan inti tersebut sebagai berikut:

a) Mengamati

Setalah mengunggah materi pembelajaran Bahasa Arab, guru menjelaskan mata pelajaran 
tersebut melalui aplikasi zoom ataupun lainnya. Pada proses ini siswa dituntut untuk mendengarkan sekaligus mengamati penjelasan dari guru. Misalnya, siswa mendengarkan tentang salah satu tema materi Bahasa Arab yang diterangkan oleh guru atau siswa mendengarkan penjelasan guru melalui mp3 yang telah dishare melalui group whatsAap, google classrom, zoom maupun youtube. Adapun kusus maharah kalam, guru menggunakan aplikasi quizizz dalam penyampaian materinya.

b) Menanya

Setelah proses mengamati berlangsung, guru memberikan waktu kepada peserta didik untuk bertanya tentang materi pelajaran Bahasa Arab. Dalam tahap ini siswa dapat menanyakan kalimat atau kosa kata yang belum dipahami tentang materi tersebut, melalui diskusi kelas di group whatsAap kelas atau google classrom.

c) Eksperiment

Eksperiment merupakan tahapan siswa untuk mempraktekkan apa yang telah diajarkan oleh guru. Misalnya dalam maharah istima' siswa disuruh menyebutkan kata yang didengar tentang materi Bahasa Arab sesuai yang ditunjukkan oleh guru, atau siswa mencocokkan beberapa kata, frase atau mufrodat sesuai dengan maknanya.

d) Mengasosiasi

Tahap selanjutnya setelah tahap eksperiment adalah tahap mengasosiasi. Dalam tahap ini siswa disuruh untuk menjelaskan ulang makna membuat simpulan wacana tentang materi Bahasa Arab yang disimak. Pada tahap ini, seorang guru bisa menilai sekaligus membedakan antara siswa yang faham materi dan siswa yang tidak faham. Sehingga dipertemuan selanjutnya seorang guru bisa memberikan perhatian yang lebih bagi siswa yang belum memahami materi yang telah diajarakan.

e) Mengkomunikasikan

Tahap terakhir dalam kegiatan inti collaborative learning adalah tahap mengkomunikasikan. Dalam tahap ini, biasanya siswa disuruh menerapkan isi materi yang telah disimak melalui baik melalui keterampilan berbicara maupun menulis dengan bahasa arab.
Selain itu, siswa juga diberikan pertanyaan seputar materi yang telah diajarkan. Kemudian siswa menjawab pertanyaan yang diajukan oleh guru tentang materi Bahasa Arab.

Figure 3: Guru menjelaskan materi dengan media you tube.

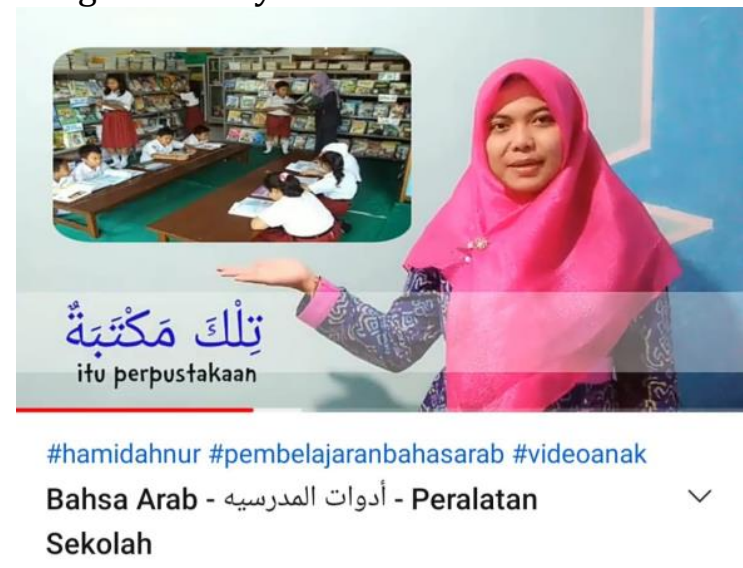

3. Tahap Evaluasi

Menurut Tyler (1973: 105) evaluasi merupakan sebuah proses guna mengukur seberapa jauh hasil pembelajaran sesuai dengan tujuan yang diinginkan. Selain itu, menurut Gilbert Sax dalam Zainal Arifin (2012: 8) menjelaskan bahwa "evaluation is a process through which a value judgement or decision is made from a variety of observation and from the background and training of the evaluator" (evaluasi adalah suatu proses dimana pertimbangan atau keputusan suatu penilaian dibuat dari berbagai pengamatan, latar belakang, serta pelatihan dari evaluator).

Pada tahap ini, guru melakukan evaluasi terhadap tugas Bahasa Arab yang telah dikirim melalui instrumen collaborative learning baik melalui gorup whatsAap kelas, google clasrom maupun yang lainnya. Evaluasi ini dilaksanakan secara online. Setelah semua tugas telah selesai dikoreksi, maka guru dapat mereview kembali secara online melalui zoom. Hal ini dilaksanakan untuk menguatkan pemahaman siswa tentang tugas atau materi yang telah disampaikan melalui instrument-istrumen collaborative learning.

\section{Kelebihan dan kekurangan pembelajaran e- learning di SD Islamic Global School}


Fokus terakhir yang dikaji dalam penelitian ini adalah kelebihan dan kekurangan implementasi e-learning di SD Islamic Global School. Pengambilan data dalam bagian ini melalui wawancara dengan Hamidah, S.Pd selaku guru Bahasa Arab di SD Islamic Global School. Berdasarkan hasil analisis, kelebihan pelaksanaan e-learning dapat dijelaskan sebagai berikut:

Pertama, Memberikan kesempatan bagi siswa dan guru untuk lebih kreatif dan inovatif dalam pembelajaran Bahasa Arab. Di dalam pembelajaran e-learning siswa dan guru dituntut untuk berfikir serta bertindak lebih kreatif dan inovatif guna menciptakan suasana kegiatan belajar mengajar yang menyenangkan, kususnya dalam pembelajaran Bahasa Arab. Hal ini senada dengan pendapat Jethro, et., al (2012: 210) yang menyatakan bahwa dengan pemanfaatan teknologi dengan baik dan benar, maka senantiasa guru dan siswa dapat menemukan cara-cara baru dalam proses kegiatan belajar mengajar.

Kedua, Memberikan waktu yang fleksibel dalam pembelajaran Bahasa Arab. Menurut Hamidah pembelajaran Bahasa Arab secara daring ini tidak terpaku dengan jadwal yang telah ditetapkan oleh pihak sekolah. Penjadwalan pembelajaran daring ini menyesuaikan dengan kesepakatan antara siswa dan guru yang didiskusikan di group wahtsAap kelas. Jadi, untuk masalah waktu dalam pembelajaran ini lebih fleksibel. Hal ini senada dengan pendapat Mutia \& Leonard (2013: 283) yang menyatakan bahwa pelaksanaan e-learning memungkinkan siswa dan guru memiliki waktu yang fleksibel dalam melakukan proses belajar mengajar.

Ketiga, Memberikan kemudahan akses terhadap sumber belajar. Pemanfaatan teknologi dan internet dalam pelaksanakan e-learning memberikan kemudahan bagi siswa dan guru untuk mengakses sumber belajar. Cukup dengan smartphone atau laptop yang terhubung dengan internet, dapat mengakses materi yang akan dipelajari. Sehingga, dengan adanya e-learning ini dapat melakukan kegiatan pembelajaran di mana saja, dan kapan saja.
Selain kelebihan penggunaan e-learning, penelitian ini juga menemukan beberapa kekurangan dalam pelaksanakan e-learning pada pembelajaran Bahasa arab di SD Islamic Global School. Hasil analisis terhadap kekurangan dalam pelaksanakan e-learning akan dijabarkan sebagai berikut: Pertama, tidak semua siswa memiliki HP android ataupun laptop guna menunjang pelaksanakan pembelajaran berbasis e-learning. Menurut Hamidah guru Bahasa Arab SD Islamic Global School terdapat 3 siswa yang tidak memiliki HP android ataupun laptop. Jadi, ketika proses pembelajaran berlangsung siswa tersebut harus bergabung dengan salah satu teman sekelasnya. Selain itu, Bu Hamidah terkadang juga mendatangi rumahnya guna memberikan latihan soal sesuai materi yang telah dijelaskan.

Kedua, Akses internet tidak merata. Salah satu kekurangan pelaksanakan pembelajaran berbasis e-learning ini adalah terbatasnya akses internet. Padahal menurut Mutia \& Leonard (2013: 281) bahwa untuk melaksanakan proses pembelajaran berbasis e-learning yang efektif harus memiliki perangkat dan akses internet yang baik. Hal ini terjadi, karena tidak semua murid SD Islamic Global School bertempat tinggal di daerah perkotaan yang notabenenya mudah dalam mengakses internet. Selain itu, harga pemakaian data internet juga masih dirasa cukup mahal untuk kalangan masyarakat menengah ke bawah.

Ketiga, Minimnya pengawasan serta berkurangnya interaksi antar guru dan siswa dalam proses kegiatan belajar mengajar. Menurut Hamidah dengan adanya pembelajaran daring ini, intensitas interaksi guru dan murid menjadi berkurang. Hal ini meyebabkan berkurang pula pengawasan guru terhadap siswa ketika pembelajaran daring berlangsung. Senada dengan pendapat Mutia \& Leonard (2013: 284) yang menyebutkan bahwa implementasi elearning dapat mengakibatkan interaksi antara guru dan siswa berkurang. Oleh karena itu, guna membantu proses pengawasan terhadap siswa, seorang guru bekerja sama serta bersinergi dengan wali siswa dalam pengawasan pembelajaran e-learning ini. 


\section{KESIMPULAN}

Berdasarkan hasil penelitian dan pembahasan di atas dapat disimpulkan sebagai berikut: pertama, pelaksanakan pembelajaran elearning di SD Islamic Global School menggunakan 5 media utama, yaitu: google classrom, whatsAap, you tube, zoom, dan quizizz. Kedua, implementasi e-learning dalam pembelajaran Bahasa Arab di SD islamic Global School terdiri dari 3 langkah utama, yaitu; pendahuluan, kegiatan inti, dan evaluasi. Ketiga, dalam pelaksanakan pembelajaran Bahasa Arab berbasis e-learning di SD Islamic Global School terdapat kelebihan dan kekurangan. Adapun kelebihannya ada 3, yaitu: memberikan kesempatan bagi siswa dan guru untuk lebih kreatif dan inovatif, memberikan waktu yang fleksibel, dan memberikan kemudahan akses terhadap sumber belajar. Sedangkan, kekurangannya ada 3 juga, yaitu: tidak semua siswa memiliki HP android ataupun laptop guna menunjang pelaksanakan pembelajaran Bahasa Arab berbasis e-learning. Akses internet tidak merata, minimnya pengawasan serta berkurangnya interaksi antar guru dan siswa dalam proses kegiatan belajar mengajar.

Penelitian ini memiliki keterbatasan pada objek penelitian, yakni dilakukan hanya pada satu sekolah, sehingga informasi yang diperoleh terbatas dan tidak beragam. Penelitian ini menyarankan penelitian yang seirama dengan menggunakan 2 lembaga atau multi situs, dengan demikian data dan informasi yang didapatkan lebih variatif, dan dapat dikomparasikan antar beberapa sekolah. Sekolah satu dengan sekolah lain yang berbeda lokasi (desa dan kota) akan mengalami kendala yang berbeda, begitu juga tingkat aksesibitas e-learning juga berbeda.

\section{DAFTAR PUSTAKA}

Arifin, Zainal. (2012). Evaluasi Pembelajaran. (Jakarta: Direktorat Jendral Pendidikan Islam Kementrian Agama RI).

Belaya, V. (2018). The Use of E-learning in Vocational and Training (VET): Systematization of Existing Theoretical Approaches. Journal of Education and Learning, 92-101.
Cahyani, Adhetya, Iin Diah Listiana, Sari Puteri Deta Larasati. (2020). Motivasi Belajar SMA pada Pembelajaran Daring di Masa Pandemi Covid19. Jurnal Pendidikan Islam: 3 (1), 123-140. https://doi.org/10.37542/iq.v3i01.57

Clark, R. C. \& Mayer, R. E. (2003). E-Learning and The Science of Instruction. Ossey-Bass/Pfeifer.

Damayanti, Sri Luh. (2020). Implementasi E-Learning dalam Pembelajaran Bahasa Inggris di Pendidikan Tinggi Pariwisata di Bali Selama Pandemi Covid-19. Journey: 2 (2), 63-82.

GTPPCovid-19. (2020). Protokol Percepatan Penanganan Pandemi Covid-19 (Corona Virus Disease 2019).

Henderson. (2003). The E-Learning Question and Answer Book. American Management Association.

Husna, Khairul. (2020). Proses Pembelajaran Matematika di Madrasah Ibtidaiyah Negeri 3 Langsa di Tengah Pandemi Covid-19. Pedagogik: Jurnal Ilmiah Pendidikan dan Pembelajaran 146 Fakultas Tarbiyah Universitas Muhammadiyah Aceh, 7 (2), 145155.

Jethro, O. O., Grace, A. M., Thomas, A. K., (2012). E-Learning and its effects on Teaching and Learning in a Global Age. International Journal of Academic Reasearch in Business and Social Sciences, 203-219.

Juanda, A. (2014). Integrasi Ilmu Alam (Sains) dan Agama Berbasis Kurikulum Grass Roots di Perguruan Tinggi Islam. Scientiae Educatia, 3 (1), 79-88.

Kattoua, T., Al-Lozi, M., Alrowwad, A. (2016). A Review of Literature on E-Learning System in Higher Education. International Journal of Businnes Management and Economic Research, 754-762.

Latip, Abdul. (2020). Peran Literasi Teknologi Informasi Dan Komunikasi Pada Pembelajaran Jarak Jauh Di Masa Pandemi Covid-19. EduTeach : Jurnal Edukasi Dan Teknologi Pembelajaran, 1(2), 108-116. https://doi.org/10.37859/eduteach.v1i2.1956

Mustofa, MI, dkk. (2019). Formulasi Model Perkuliahan Daring Sebagai Upaya Menekan Disparitas Kualitas Perguruan Tinggi. WJIT: Walisongo Journal of Information Tecnology, 1 (2), 151-160.

Mutia, I., Leonard. (2013). Kajian Penerapan ELearning Dalam Proses Pembelajaran Di Perguruan Tinggi. Faktor Exacta, 278-289.

M. Nurlaila, N., \& Muassomah, "The Collaboration of Herbart Method with Cooperative Learning: 
Optimizing Writing Skills at IAIN Madura.," ALSINATUNA, 5(2), vol. 5(2), pp. 147-164., 2020.

Pusdiklat Pegawai Kementerian Pendidikan dan Kebudayaan. "SURAT EDARAN MENDIKBUD NO 4 TAHUN 2020 TENTANG PELAKSANAKAN KEBIJAKAN PENDIDIKAN DALAM MASA DARURAT PENYEBARAN CORONA VIRUS DISEASE (COVID-19)," $24 \quad$ Maret 2020. https://pusdiklat.kemendikbud.go.id/suratedaran-mendikbud-no-4-tahun-2020-tentangpelaksanakan-kebijakan-pendidikan-dalammasa-darurat-penyebaran-corona-virusdisease-covid-19/.

Ralph, Tyler W. (1973). Basic Principles of Curriculum and Instruction. (London: Lowe and Brydone (Printers) Ltd.
Sugiyono. (2019). Metode Penelitian Kuantitatif, Kualitatif, dan $R \& D$. Bandung: Alfabeta.

Yudiawan, Agus. (2020). Belajar Bersama Covid-19: Evaluasi Pembelajaran Daring Era Pandemi di Perguruan Tinggi Keagamaan Islam Negeri, Papua Barat. Al-Fikr: Jurnal Pendidikan Islam, 6 (1), 10-16.

Yusi Irawati, Desrina., \& Jonatan. (2020). Evaluasi Kualitas Pembelajaran Online Selama Pandemi Covid-19: Studi Kasus di Fakultas Teknik, Universitas Katolik Darma Cendika. Jurnal Rekayasa Sistem Industri: 9 (2), 135144.

Windhiyana, E. (2020). Dampak Covid-19 Terhadap Kegiatan Pembelajaran Online Di Perguruan Tinggi Kristen Di Indonesia. Perspektif Ilmu Pendidikan, $\quad 34(1), \quad 1-8$. https://doi.org/10.21009/PIP.341.1 